\section{New Trends and Issues Proceedings on Humanities and Social Sciences}

Issue 1 (2017) 372-375

ISSN 2421-8030

www.prosoc.eu

Selected paper of 8th World Conference on Educational Sciences (WCES-2016), 4-8, February 2016, University of Alcala, Madrid, Spain

\title{
A Study on factorization questions in YGS and education in high schools
}

Ayten Ozkan ${ }^{\text {* }}$, Department of Mathematics, Faculty of Science Education, Yıldız Technical University, Istanbul 34220, Turkey.

\section{Suggested Citation:}

Ozkan, A. (2017). A Study on factorization questions in YGS and education in high schools. New Trends and Issues Proceedings on Humanities and Social Sciences. [Online]. 01, pp 372-375. Available from: www.prosoc.eu

Selection and peer review under responsibility of Jesus Garcia Laborda, University of Alcala, Spain ${ }^{\circledR} 2017$ SciencePark Research, Organization \& Counseling. All rights reserved.

\section{Abstract}

We investigate the relation between factorization of Higher Education Examination (YGS) questions and factorization education at schools in Turkey. The sample of study consist of the students of some Anatolian high schools in Istanbul. This study presents the closeness of this relationship, the result of arising inadequacies, and suggestions.

Keywords: Factorization, misconception , mathematical education.

* ADDRESS FOR CORRESPONDENCE: Ayten Ozkan, Department of Mathematics, Yıldız Technical University, Davutpaşa Campus, 34220 İstanbul.

Turkey E-mail address: uayten@yildiz.edu.tr / Tel.: +90-212-383-4331. 


\section{Introduction}

The purpose of this study was to determine misconceptions of 10th grade students in the subject factorization. Taken in secondary education system serves as a bridge between elementary and higher education. When the high school mathematics curriculum structure is analyzed at the end of this program, students will be able to us mathematical concepts in everyday life and system of establishing relationships between them and understand in other areas of learning. According to Baki (2008) some students when learning something new which they draw on previous knowledge . They have information available, it is sometimes leads to misconceptions in the learning of new concepts. Therefore be decisive in organizing training programs to better understand the role playing to learn the issues in the 10th grade math class determination of students in the upper difficult issues. In high school mathematics program conducted to determine difficult were encountered in some studies. Factorization is a reasonable basis to other issues must comprehend well. Students errors on factorization is associated with success in YGS suggest solutions to these deficiencies will be presented. The sample of the study consists of 25 10th grade students in a high school in istanbul Kagithane Anatolian high school .Data were collected by a multiple choice which has 13 questions about subject. The results of the study indicated that were high success in operations with factorization and low success in factorization of variables and equations with factorization. By the results of the study the students' rate of success was calculated for the questions.

Students achievement on the multiplier for the purpose of research questions designed to measure skills related to separation cases were analyzed for each question.

\section{Methods}

Experimental research methods are used in this study. Research for measuring tool for students for use as a question consisting of 13 test questions regarding the gains is prepared. A data questionnaire to be implemented as a collection tool to 10th grade students and 7 have also emerged YGS exam question 6 is prepared questions taken from the 10th grade book. Student achievement on the multiplier for the purpose of research questions designed to measure skills related to separation cases have been analyzed for each questions.

\section{Question 1:}

Factorize $5 x^{2}-4 x-1=$ ?

\section{Question 2:}

$$
\text { Factorize } 24 x^{2}-36 x-24=\text { ? }
$$

Question 3:

$$
\text { If } x^{2}-m x+6=(x+3)(x+n) \quad m+n=?
$$

Studies show that students perceive the subject of the basic concepts of separation factor less pressured.

Table 1

\begin{tabular}{lll}
\hline & $\begin{array}{l}\text { Number of } \\
\text { students }\end{array}$ & $\mathrm{F} \%$ \\
\hline True & 16 & 64 \\
False & 4 & 16 \\
None & 5 & 20 \\
\hline
\end{tabular}


Question 4:

Question 5:

$$
\text { If } \quad \begin{aligned}
a+b+c & =A, \text { find } \quad A^{2}-B^{2}=? . \\
a-b-c & =B
\end{aligned}
$$

Simplify $(a+1)^{2}-(a-1)^{2}=$ ?

Question 6:

$$
\frac{1}{x+1}+x-1=\frac{1}{x^{2}} \text { then find } x^{3}-1=?
$$

Question 7:

$$
\text { Simplify } \frac{a^{2}-2 a-3}{\left(\frac{1}{a}+1\right)\left(\frac{3}{a}-1\right)}=?
$$

Question 8:

$$
\text { If } \quad \frac{2^{x^{2}-y^{2}}}{4^{x^{2}+x y}}=\frac{1}{2} \quad \text { find } \quad(x+y)^{2}=?
$$

Question 9:

$$
\begin{array}{ll}
\text { If } & a^{2}-a=b^{2}-b \\
& a \cdot b=-1 \quad \text { find } \quad a^{2}+b^{2}=?
\end{array}
$$

Table 2

\begin{tabular}{lll}
\hline & $\begin{array}{l}\text { Number of } \\
\text { students }\end{array}$ & $\mathrm{F} \%$ \\
\hline True & 5 & 20 \\
False & 14 & 56 \\
None & 6 & 24 \\
\hline
\end{tabular}

It has been shown to make a mistake because the underlying issue of the lack of knowledge of students and enough examples of the above questions are resolved.

Exponents should be taught to these issues. The factorization should be placed on relations with other issues.

The results of the study indicated that there were high success in operations with factorization and low success in equations with factorization

\section{Conclusion}

When considering the results obtained by students in general it has been shown to superficial information by factorization and memorizing formulas. Besides the issues connected with factorization and was observed to fall YGS success. Students fell into misconceptions that question better analyze. It was found in the questions that are more heavily in the concept misconceptions. To practice on this issue is very important for students. While teaching subject should be given the operational 
Ozkan, A. (2017). A Study on factorization questions in YGS and education in high schools. New Trends and Issues Proceedings on Humanities and Social Sciences. [Online]. 01, pp 372-375. Available from: $\underline{\text { www.prosoc.eu }}$

and conceptual information. The subject should be given to prepare for the YGS exam. The time allocated to the subject matters at school should be increased.

\section{References}

Ausubel, D.P. (1960). The use of advance organizers in the learning and retention of meaningful verbal material. Journal of Educational Psychology. 51. 267-272.

Baki.A. (2008). Kuramdan uygulamaya Matematik Egitimi. Ankara: Harf Egitim Yayinciligi.

Baykul . Y.(1999). İlkOgretimde Matematik Ogretimi, Ogretmen El Kitabı: Modul 6, Ankara, Milli Egitim Yayınları.

Ozkan, A. Ozkan, E. M. (2010). Mutlak deger konusunda yapılan kavram yanılgıları. International Conference on New Horizons in Education, INTE, KIbrIs, 23-25 June.

Skemp,R . (1978). Relation understanding and instrumental understanding. Arithmetic Teacher, 26, 9-15. 